\title{
THE USE OF ENGLISH MEDIA IN EARLY CHILDHOOD
}

Author:

Magdolna Nemes (PhD.)

University of Debrecen Faculty of Child and Spe-

cial Needs Education

(Hungary)

E-mail adress of the first author:

nemesm@ped.unideb.hu

\section{Lectors:}

\author{
Katalin Mező (PhD.) \\ University of Debrecen \\ (Hungary) \\ Ferenc Mező (PhD.) \\ Eszterházy Károly University \\ (Hungary)
}

Nemes M. (2019): The use of English media in early childhood. Különleges Bánásmód, 5. (1). 49-57. DOI

10.18458/KB.2019.1.49

\begin{abstract}
The flow of information in the digital age is facilitated not only by traditional media such as television, radio and print but also by new media such as the internet, desktops and integrated computers, tablets and smartphones etc. The presence of IT tools is quite common these days among kindergarten aged children (3-6/7), and even toddlers can use them on a daily basis. Moreover, modern pedagogy is unthinkable without digital devices that have become integral parts of innovations such as game-based learning, mediabased learning and edutainment. There are several language schools and bilingual creches where they accept very young children and babies. It is said that parents knows their child best and children spend a lot of time with their parents. In consequence, this provides an excellent opportunity for parents to raise a bilingual child even if it is not his/her first language. In our paper we are combining these two, currently central issues: the use of English-language media and early childhood language-learning, as only limited research is available about it. We are going to present the results of empirical research carried out mainly in kindergartens in Debrecen, which focused on early second language learning and the children's use of media. Our research has two goals, so the questionnaires asked parents about the use of foreign-language media, its content and the time children spend consuming English content. In addition, we were interested in the parents' attitude to their children's English-language media use. We analyzed our data in the framework of early second language learning. Our research was carried out within the Early Childhood Research Group run by the Faculty of Education for Children and Special Educational Needs of the University of Debrecen. The research was carried out between October 2016 and January 2017.
\end{abstract}

Keywords: early childhood, media, English-language media

Discipline: pedagogy

\section{Absztrakt}

AZ ANGOL NYELVŰ MÉDIA HASZNÁLATA KORA GYEREKKORBAN

A mai digitális világban veszélyes gyermeknek lenni. A gyerekek számára a technológia, a média tálcán kínálja az információkat, amit egy gyermek az életkori sajátosságai miatt nem minden esetben tud megfelelően értékelni. Az információ áramlását a médiaeszközök teszik lehetővé, mint a televízió, rádió, internet, tablet, telefon, számítógép, melyek használata rendkívül elterjedt napjainkban. Az internet-szolgáltatás mára elérhetô a családok számára, és IKT eszközök segítségével a gyermek anyanyelvi szinten hallhatja az idegen nyelvet, amit a vizuális-auditív ingerek tesznek élménnyé. A 21. század elején a másik központi kérdés az idegen nyelv, elsősorban az angol nyelv ismerete. A szülők gyermekük érdekeit és majdani iskolai kötelezettségeit szem előtt tartva már a korai életkorokban beíratják óket idegen nyelvú tevékenységekre, köztük óvodai angol tevékenységekre, de a szülő otthon is megismertethet egy másik nyelvet gyermekével, valamint néhány hónapos kortól nyelviskolába is járhat a gyermekkel. Saját megfigyeléseink ösztönöztek arra, hogy érdemes a kora gyermekkor és az idegen nyelvú média kérdéseivel foglalkozni, hiszen a gyermekek életében is megjelennek az IKT-eszközök és használják is azokat. Dolgozatunkban azt mutatjuk be, hogy ezen eszközök alkalmazása már nem csak a felnőttek kiváltsága, hanem a legkisebbeké is, esetünkben a 3-7 éves gyermekeké. A médiának a nyelvi szocializációban is fontos szerepe van: az internet és IKT eszközök segíthetik az idegen nyelvek elsajátítását. Az informatika a jövő záloga, ami magával vonzza az 
idegen nyelv tanulásának szükségességét és új lehetőségét is. Dolgozatunkban egy, debreceni óvodákban készült empirikus kutatás eredményeit (a vizsgálat ideje: 2016. ősztől 2017 tavaszig, $\mathrm{N}=60$ ) is megjelenik, melynek tárgya a gyermekek korai idegen-nyelv elsajátítására és a gyermekek médiahasználatára irányult. A kérốives vizsgálat a szülőket az idegen nyelvủ médiumok használatáról, tartalmáról és idejéről kérdezte, valamint a szülói attitűdöt is vizsgálta. A vizsgálatunk nem reprezentatív, de megfelelő alapot ad számunkra, hogy megismerjük a kora gyermekkori angol nyelvű médiahasználat megjelenését napjainkban. A téma szélesebb körű reprezentatív módon történő vizsgálata is időszerűvé vált.

Kulcsszavak: gyermekkor, média, angol nyelvű média

Discipline: pedagógia

\section{Introduction}

The flow of information in the digital age is facilitated not only by traditional media such as television, radio and print but also by new media such as the internet, desktops and integrated computers, tablets and smartphones etc. The presence of IT tools is quite common these days among kindergarten aged children (3-6/7), and even toddlers can use them on a daily basis. A lot of children get a tablet as a present from their parent or grandparents when they leave kindergarten at the age of $6 / 7$. Moreover, modern pedagogy is unthinkable without digital devices that have become integral parts of innovations such as game-based learning, media-based learning and edutainment.

At the beginning of the 21 st century, one other central question is the value of language skills, and in particular English language competence. English has become the language of cross-cultural communication as it is the primary language of business, media (e.g. films, music, online games) and tourism as well. Countless teenegers watch their favourite series and streams in English in their free time and pick up the language unconsciously. English is used in business conversations around the world, and not just between business partners one of whose first language is English. English is also used as a working language by many multinational companies. English is also the common ground of business meetings, emails and international communication, and it is possible to follow a wide range of different courses in English at many universities around the world. A lot of students study abroad with the help of scholarship or exchange programmes such as Erasmus+.

Also, foreign holidays, spending time in a new social envrironment and keeping in touch with friends require a certain level of language competence. English is at present used as the world's lingua franca making it the essential intermediary language of communication.

\section{Background}

To achive the goal that every European citizen should speak at least two foreign languages at B2 level, starting to learn languages at an early age is necessary. The Eurpoean Union launched the Piccolingo program in 2009 in order to promote early language learning. The programme suggests that parents start early language learning with their children as early as possible because the susceptibility of the early years, and the flexible neuron network never come back. Due to the brain's plasticity, the younger a child starts learning a language, the more succesful he/she will be in that endeavour. Age has an impact on the process of language learning and its success is in close interaction with other factors (Nikolov 2004). "The most important goal of early language learning is to create a positive attitude to language and to keep motivation as these are fundamental for further language learning. In childhood acquiring a second language is very similar to acquiring the first language. The child, with the help of his/her innate analytical skills acquires the foreign language in a natural way if she/he gets enough quality and quantity input. At that age there is no need for direct language teaching, the goal of the English activities is not to drill words and grammaical structures, however, the aim is global understanding" (Varga 2008 translated by Magdolna Nemes).

A lot of parents nowadays find it important that their children should learn a second language. In Hungary there have been English activities in many kindergartens since the change of political regime in 1989 with the support of the state. Gabriella Muszka contacted all 46 kindergartens in Debrecen in 2013 and it turned out that 25 kindergartens (54\%) offered English activities for children. (Muszka 2013: 12). In 2017 in Nyíregyháza there were 34 state-run kindergartens of which 23 organized English activities for children (68\%) (NemesNagy 2018). 
Besides the above mentioned state kindergartens, there has been a demand for early English in private institutions. Since we carried out our research in Derbecen, let us see what options can be found there for early English. There are several language schools and bilingual creches where they accept very young children and babies (such as Csodabogár Bilingual Creche). There have been Helen Doron Learning Centres in Hungary since 2002 offering courses to children aged three months old until the age of 18 (Teen English). Helen Doron courses for children have been available in Debrecen ever since the method arrived in Hungary. The basic principles of Helen Doron Early English courses for children are positive reinforcement, the lessons are funny, dynamic, playful and activate all the senses (Doron 2010). Another example of shadow education is The Kids Club which also deals with young English learners. The method, based on first language acqusition, was developed in 1988 by Linda Ellis, a language teacher in the United Kingdom. The Kids Club has courses for children from as early as 6 months old. Helen Doron Early English Learning Centres and The Kids Club also offer summer camps. Children living in Debrecen can also go for English lessons to Oxford Language School or Kids \& Teens courses organized by Katedra Language School (bttps://debrecen.katedra.bu). Ezüstcsiga is also a private school situated in the heart of the city where children can learn English from the age of 3 (bttps:/ / ezustcsiga.bu).

It is said that parents knows their child best and children spend a lot of time with their parents. In consequence, this provides an excellent opportunity for parents to raise a bilingual child even if it is not his/her first language (Saunders 1988, KingFegle 2006, Pearson 2008). When Hungarian parents decide to introduce their child to the mysteries of English, there are a lot of availabe sources. First, there are online blogs written by parents who communicate with their child(ren) in a language different from their first language (e.g. www.ketnyelvugyerek.hu, www.angolkalauz.hu). The first language of these parents (who are usually mothers) is Hungarian but they have decided to speak English with their children. The parents who choose this kind of method are usually language teachers or else lived in an English-speaking country for quite a long time. Annamária Bán published a book on how to raise your child being bilingual (Bán 2013) and also started the very first website (www.ketnyelvugyerek.hu) and blog in this field in Hungary. The writers/bloggers give a great deal of useful advice and playful ideas based on their own experience (e.g. Fürész-Mayernik 2015).
The British Council supports home English learning with free downloadable materials within the programme called Learn English Family and also organizes courses for parents interested in the method (Fehér 2014). Publishers also have special books, CDs and exercise book for parents to teach English at home. Oxford University Pressed published Cookie and his friends, containing not only a course book but also an activity book, a parent's guide, a multiROM and reward stickers (Reilly 2005, 2011). Cambridge University Press published Hippo and Friends, a three-level pre-school course for 3-5 year-olds. It uses a song and story-based approach to introduce language to children in a way that comes naturally at this age. Actions and activities further reinforce learning. The course is packed full of attractive illustrations. Extra components such as Flashcards, a Hippo puppet, Story Posters and a book of Photocopiable Extras and a Pupil's Books with activity stickers are also available and help the parents (Selby-McKnight 2006).

In our paper we are combining these two, currently central issues: the use of English-language media and early childhood language-learning, as only limited research is available about it. We are going to present the results of empirical research carried out mainly in kindergartens in Debrecen, which focused on early second language learning and the children's use of media. Our research has two goals, so the questionnaires asked parents about the use of foreign-language media, its content and the time children spend consuming English content. In addition, we were interested in the parents' attitude to their children's Englishlanguage media use. We analyzed our data in the framework of early second language learning. We have to underline that our research is not intended to be representative but is a pilot project. However, our data provide us a resource through which to investigate this new topic from a number of different perspectives.

We believe that the parents asked are very conscious concerning their children's language learning. We also presume that children consume not only Hungarian but also English language media contents.

\section{Foreign language acqusition and the use of media among children aged 3-6}

\section{Circumstances of the research}

Our research was carried out within the Early Childhood Research Group run by the Faculty of Education for Children and Special Educational Needs of the University of Debrecen. The research 
was carried out between October 2016 and January 2017. The kindergardens taking part in the research were:

Training Kindergarten of the University of Debrecen - Hajdúböszörmény, Közép utcai Óvoda [Kindergarten in Közép Street], Áchim András utcai Ovoda [Kindergarten in András Áchim Street], Debreceni Egyetem Óvoda [Kindergarten of the University of Debrecen], Százszorszép Óvoda [Szászorszép Kindergarten], Táncsics Mihály utcai Óvoda [Kindergarten in Mihály Táncsics Street] - Debrecen.

The printed questionnairies were distributed in kindergarten group where English acitivites are available at least once a week. In the groups 15-50 questionnairies were distributed, altogether one hundred. From the questionnairies distributed we got 59 back $(59 \%)$. In the questionnaire we asked the parents 30 closed and open-ended question. The questionnaires were filled in voluntarily, the answers are based on self-assessment. In the research project the key questions were asked at the beginning of the questionnaires and ethical approval was received from the parents and from the heads of the institutions as well.

The topics of the research:

I. Personal data

II. General data about the use of IT tools and internet

III. Use of media in foreign languages and their contents

IV. Parents' opinion about early language learning

$\mathrm{V}$. The expectations of the parents

\section{Analysis of the data}

According to their place of residence, one family live in a village, 16 families live in a town and 42 families live in the city of Debrecen, the second largest settlement in Hungary. The village (Bocskaikert) and the town (Hajdúböszörmény) are in the agglomeration of Debrecen.

As for the language(s) spoken at home, most familes use Hungarian in the family, in the very first socializing environment for a child (55). It may seem to be an unimportant question, but due to marriages/cohabiting, working or studying abroad, more than one language can be used in a family. Being bilingual is a common phenomenon in many parts of the world, but not in Hungary, where most of the inhabitants are monolingual. Generally, bilingual children have parents of two different first languages.

In our sample there are two families where English and Hungarian are used for communication.
Ukrainean (1) and Polish (1) are also spoken in the families involved. Also, there are non-native parents who raise their children in the target language that is not their first language (Heller 2010). Those parents who don't use the above-mentioned methods can employ a native au-pair or baby-sitter or decide to send their child(ren) at a very early age to a language school.

If we take a look at the number of children in a household, we can see there is one child in a third of the families involved (32). In most families there are two children (26), which is the typical Hungarian family pattern. In 13 families there are 3 children and there are 4 children only in one family (Figure 1.).

We also asked the age of children in the groups. As we can see most children are 5 years old (23 children) or 6 years old (24 children). A third of the children (21) are under the age of five. This has something to do with the fact that we asked parents whose children take part in English activities in the kindergarden, and in several institutions this option is not avalaible for very young children (3-4 year olds)

We looked at the age of the parents according to their gender. Based on our data, there are four mothers between 25-30, 15 mothers belong to the age group between 31-35, though most of the mothers involved in our research were between 3640 (26 mothers) and 14 mothers were between the ages of 41-45. As for the fathers, we can say that there aren't any respondents under the age of 30 . 12 fathers are between 31 and 35 years, 23 between 36-40, 22 fathers between 41-45. and 2 fathers who are more than 46 years old. The reason behind the ages of the parents may have different interpretations. It is possible that their first child is not in kindergarten. Another reason can be that nowadays parents start families later

Most mothers involved in our research graduated from a college and/or university (43), 10 of them have a general certificate of education (GCSE), five of them graduated from a vocational school and one of them has primary school education. As for the fathers, 30 of them graduated from a college and/or university.

Three of them hold a technical education, 16 have a general certificate of education (GCSE) and 10 of them are skilled workers. From our date we can conclude that the majority of our respondents are adults holding a degree, living in a city and they belonging to the (upper) middle class.

Gathering information about the level of language skills spoken by the parents was also important for us. Forty-four of the mothers involved in the research speak at least one foreign language, while 14 
of them do not speak any language apart from Hungarian, and one respondent did not answer the question. As far as the fathers are concerned, 37 of them speak a foreign language, 20 of them do not speak any foreign language, and 2 fathers did not answer the question. It seems to us that in half of the families involved, both parents speak a foreign language. However, in a fifth of the families, neither of them does. Most parents (34 mothers, 41 fathers) speak English, while 11 parents speak German. Our results are not surprising, as in Hungary in order to get a degree, students have to pass a language exam at least at B2 level. (Figure 2).

In case they do not have an intermediate level language exam, they can not get their degree.

Unlike our sample, avarage Hungarian adults in the age group in question do not speak foreign languages. According to Eurostat data, Hungary has been for many years at the bottom on the list of languages spoken by the citizens in EU countries. In Hungary only $37 \%$ of the population aged 25-64 can speak at least one language in addition to Hungarian. The most widely spoken language among Hungarians is English, though based on their selfevaluation, only a quarter of them can speak English well and half of them speak English at basic level (eduline).

Nowadays it is indispensable to have internet and/or wifi connection in everyday life. According to a survey in 2014, 97\% of Hungarian households have a TV set, so 9 million citizens over the age of 4 live in a household with at least one TV set. Moreover, approximately $80 \%$ of Hungarian households have internet connection in their homes (Kósa 2015) though we believe this numbers has risen since then. As for our respondents, there was internet connection in 26 families, and wifi in 19 families. 15 parents replied that they have access to both Internet and wifi.

The use of IT tools (tv, internet) is an integral part of everyday life at the beginning of the $21 \mathrm{st}$ century and they are taking up a larger space in children's lives as well. Comparing Hungarian data to international ones, we can see outstanding levels of media consumption in Hungary. Children under the age of 17 spend more than 3.5 hours watching television a day but the use of other media (internet, magazines, radio etc.) is also siginificant (Kósa 2015). We wanted to know how many minutes/hours children in the families involved in our survey spend using IT tools. The parents could chose from the intervals given. 27 respondents $(45 \%)$ answered that their child uses IT tools for 12 hours a day, while 3 respondents answered 3-4 hours a day. None of the respondents said that their child spends more than 5 hours a day using IT tools. 13 parents $(22 \%)$ replied that their child uses IT tools once or twice a week. In 15 of the families consulted, kindergarten-aged children use IT tools three or four times weekly. Only one parent answered that his/her child uses IT tools only a few times a month. From the replies we can see that almost half of the children use IT tools for 1-2

We also asked how old the child was we he/she got to know IT tools. Most children were 3-4 years old when they first used a smartphone (16 children) a tablet (12 children) or a laptop (17 children). There were also children who started using IT tools a bit later than that, at the age of -5-6 (smartphone 17, tablet 10, laptop 13 children). However, there are also children who first used IT tools as the age of 1-2 (smartphone 4, tablet 5, laptop 4 children).

Figure 1.: Number of children in a household. (Source: Authors' own editing)

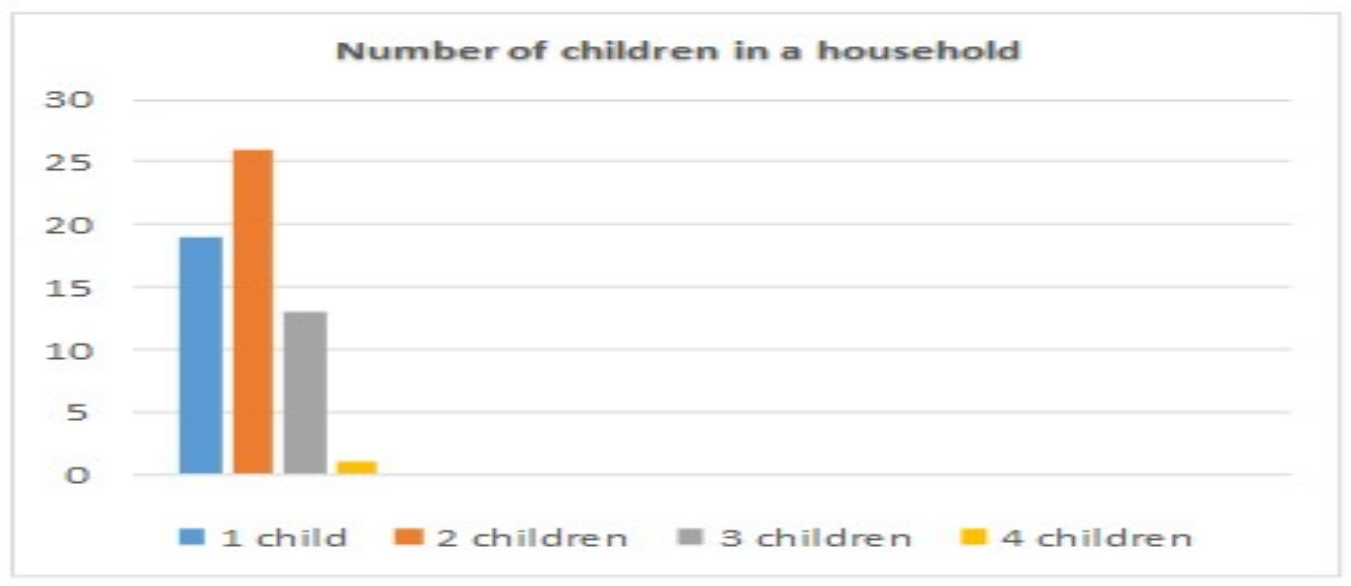


Figure 2.: The foreign languages spoken by the parents (Source: Authors' own editing)

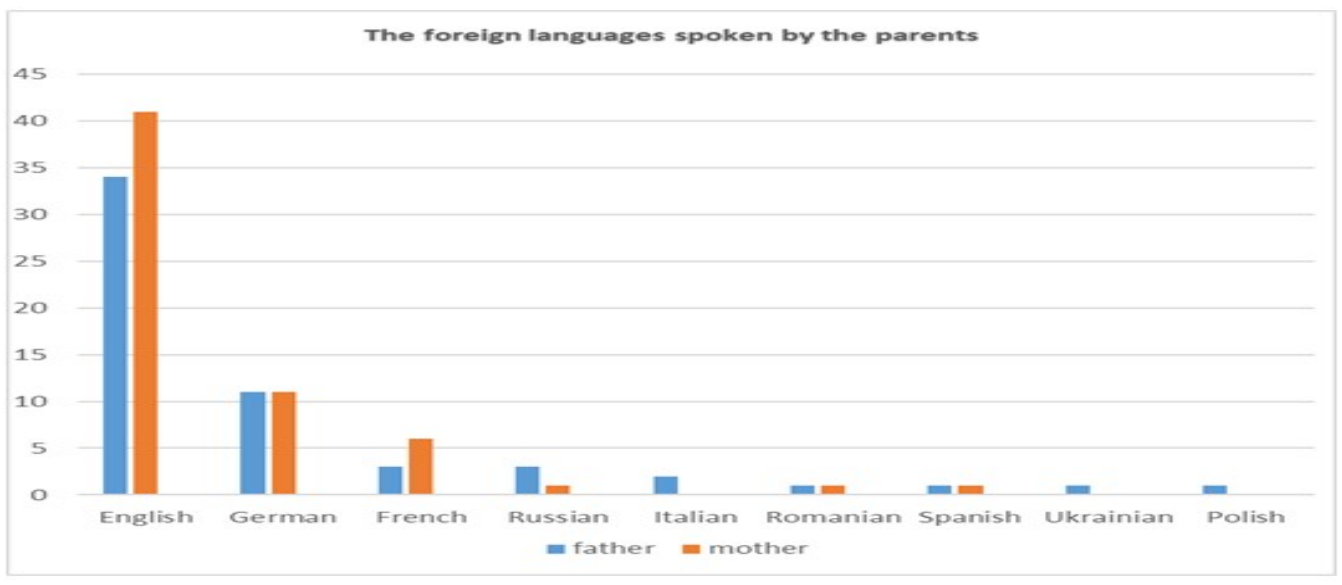

These numbers prove that IT tools are integral part of everyday life from an early age nowadays.

In the following we also wanted to know if children use IT tools to consume foreign language content. 41 respondents $(70 \%)$ answered that his/her child watches programmes in a foreign language while 17 respondents $(28 \%)$ answered his/her child does not watch any programmes in a foreign language, and one parent did not answer this question.

We were also interested to know what IT tools children use to get in touch with foreign language contents (TV, smart phone, tablet, desktop computer, laptop, book, other). The answers show a colourful picture: 37 respondents said their child watches programmes in a foreign language on TV, 28 respondents answered that their child uses a desktop computer and/or a laptop for this reason. 16 respondents mentioned tablets and 11 picked smart phones. Ten children get in touch with foreign language content while reading a book. As other options, two parents mentioned DVDs and musical toys. Only one parent replied that his/her child does not get in touch with foreign language contents at home, while 8 parents did not reply to this question. To sum up what has been said before, we can conclude that children of the respondents get in touch with IT tools, mainly the TV set in the household and/or computer, and about twothirds of them watch foreign language media content. According to our respondents, most of their children consume English language media on an IT tool for not more than one hour a day (Figure 3.). "[Our child] can watch only useful developmental programmes (English, logics) we choose and for a limited period of time" (Questionnaire 11). It has also become clear to us from the answers that the most popular TV channels are Minimax, but Cartoon Network, Disney Junior, Nickelodeon, and Baby TV are also popular. A significant share of children watch English language contents on YouTube (41 respondents, 69\%). Children enjoy watching English and American cartoons or tales e.g. Dora the Explorer, Numberjacks, Ben and Holly's Little Kingdom, Frozen, Barbie, My Little Pony, Peppa Pig, Caillon, Fireman Sam, Octonauts, City Heroes, Tayo, Heroes of the City, Paw Patrol as well as nature programmes. The parents have also listed programmes for children, songs and rhymes such as $A B C$ songs, The wheels on the bus, Super Simple Songs.

Watching English programmes and contents offer an excellent opportunity for children to listen to words, sentences and phrases used in every day life in their contexts. The parents involved find consuming English media most useful from the perspective of vocabulary and pronunciation.

Children watch English contents or with their parents (32), or on their own (27). Honestly, this is when I do the washing up (Questionnaire 20) (Figure 4.).

Comparing books read out to children in foreign languages and TV programmes watched in foreign languages we can see the most striking results. According to the answers, only 11 children $(18 \%)$ get in touch with books in English, when their parents read them about tales or rhymes sometimes. However, most children involved $(70 \%)$ watch English TV programmes, while only a third of them (17 children) do not. We also have to add that these children might use other technology tools (e.g. ready-made applications on a smartphone) to access English language contents (Figure 5.).

The parents were also asked to justify their answers. Our respondents find playful language learning the most important. "Learning is easier in a wellkonow environment in a playful way." - answered a mother in her thirties with an MA/MSc qualification (Questionnaire 30). 
Figure 3.: Watching TV programmes/shows in foreign languages. (Source: Authors' own editing)

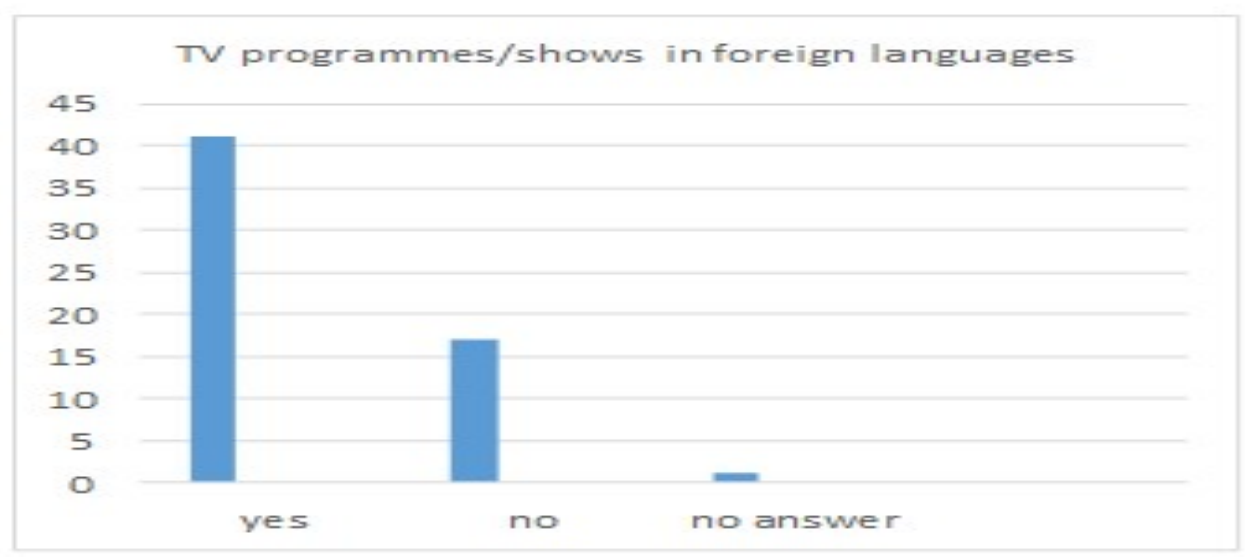

Figure 4.: Parents and children watching programmes in foreign languages together. (Source: Authors' own editing)

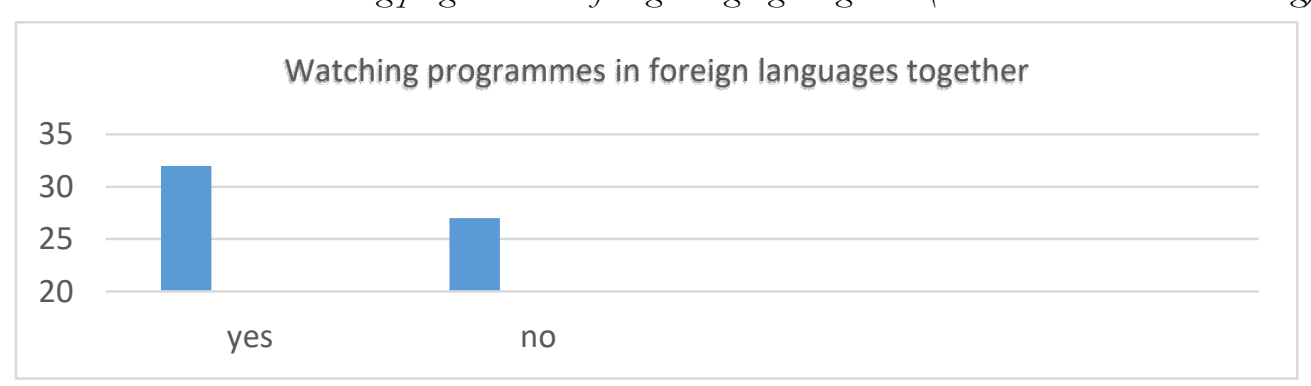

Figure 5.: Books read in foreign languages. (Source: Authors' own editing)

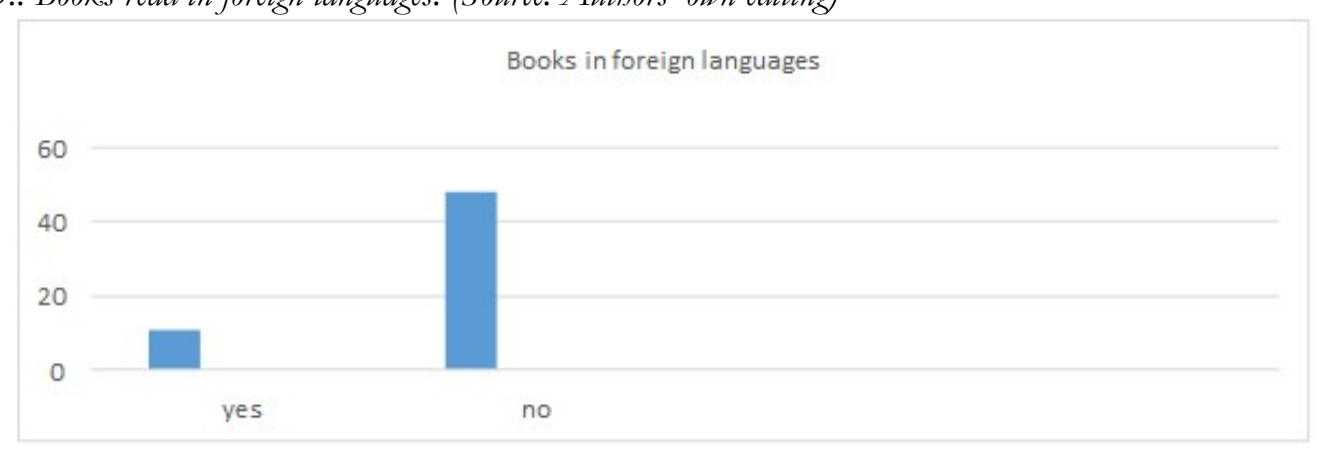

Fifteen parents believe that the child can pick up the right pronunciation and can learn some basic words and phrases in the right environment. In the answers of the parents we can see the signs of thinking about the longer-term future. They also added that if a child starts learning a language in kindergarten then he/she has only to revise it at school (12 respondents).

The children between the age 3 and $6 / 7$ have time to get to know another language, furthermore it is easier for the parents, as they do not have to take the child to a language school in the afternoon (2 respondents). Foreign language competence also develops the child's personalty and boosts his/her self-esteem (1) „We want our child to meet the target language environment in a playful way as early as possible; he will express bimself without inbibitions" (Questionnaire 32). Two responding parents underline that speaking language(s) has become fundamental in recent decades.

Later on we were interested in parents' attitude to learning languages at an early age. The parents asked find it important that their children could speak a foreign language $(98 \%)$. Most parents used phrases such as it is necessary, it's easier getting along in life which mean they recognise the social and economical expectations. Moreover, they would like their children to get along easier in life hoping that English, or foreign language competence, will help 
them to achive success and contibute to social mobility. According to one parent: [The child] can be more confident abroad, has a better chance to get a got position at work, also it strenghens the self-esteem and develops the personality (Questionnaire 53). The answers also refer to the future of the children: foreign language competence makes school studies easier and leads to a better job in the future.

Last but not least we wanted to know what are the parents' opinions about learning English in kindergarten. Most of our respondents (56) find it good and useful that their children can take part in English activities even in kindergarten. Two of the respondents do not approve of that and one parent did not reply to this question.

Finally, we asked the parents what are their expectations from language learning in kindergarten. One of the most common answers was language learning in a playful environment (24). These parents feel playfulness makes learning new information easier for the children, adding that they will be happily involved in the learning process. "The children learn the basic vocabulary, expressions, sentences in a playful environment and it motivates them to learn languages" (Questionnaire 11). The parents also mentioned love of learning languages and acquiring basic vocabulary too. In the framework of English in kindergarten it is enough to teach the basic vocabulary to children which prepares them for English lessons at school where they will be in a better position compared to those children who did not take part in English activities before. A few parents expect English activities to boost the child's self-confidence (3). I expect the child to be more brave, be brave enough to speak English, to sing and say rbymes in English (Questionnaire 5). One parent said he/she has no expectations in connection with English in kindergarten.

In the final part of our project we asked parents's views about learning languages with the help of IT tools. Based on the answers, 37 respondents approve that language learning should be supported by IT tools in kindergarten. 16 respondents disapprove of that, three respondents could not decide and three respondents did not reply to this question.

Those parents who approve of learning languages with the help of IT tools in kindergarten justified their answers as follows: it helps with learning the language, because the child learns in a playful way (21); it is a basic requirement nowadays (3), children can access knowledge and information quickly (3); IT tools are reasonably priced (1). There was a respondent who emphasized that use of IT tools in kindergartens should only be as supplements.

Those parents who disapprove of learning languages with the help of IT tools in kindergarten also justified their answers: in a playful environment personal touch is better for language learning (11); the traditional method is good (8). Two respondents stated that learning a language in kindergarden does nor require the use of IT tools.

\section{Summary}

Our own obervations encouraged us to carry out a pilot research project in the fields of early childhood and English media as IT tools have appeared in children' lives and they use them. In ou paper we have explained that the use of IT tools is not the adults' privilege any more, indeed, young children including children between 3 to $6 / 7$ also use them frequently. From the anwers we got from the prents asked, it turned out that internet access is availabe for most families, so children have access to Hungarian and English contents too, so media is a free language stage. Media play an important role in language socialization: internet and IT tools can support learning languages. It has also turned out from the answers that most children $(62 \%)$ regulary watch programmes, cartoons or tales in English with the help of modern electronic devices (e.g. laptop, tablet, smart phone).

The lesson we have learned from our research is that parents with higher qualifications get ready on purpose to develop their children's language competence. The parents enrol their child at an early age to English activities including English activities in kindergarten, keeping in mind the child's future responsibilities and interests at aschool. It has also turned our from the answers that most parents support the use of IT tools in early language teaching. However, there is a quite high percentage of parents who disapprove of that.

Information Technology is the key to the future that brings along with it the necessity and also new opportunities for languge learning. It is indispensable to draw children's attention to the rules for using IT tools, and keeping those rules in the kindergarten as well as at home within the family. The use of IT tools in kindergarten depends on their availability in the institution and the preparedness of the kindergarden teacher, who has to find the balance between traditional methods and the use of modern multimedia devices.

\section{REFERENCES}

Bán, A. (2013): Nevelj kétnyelvú gyereket! [Raise a Bilingual Child!] szerzői magánkiadás, h.n.

Doron, H. (2010): A nyelv zenéje [The music of language]. Helen Doron Early English Országos Franchise Központ, J. G. K. Kft. Budapest 
Fehér, J. (2014): A British Council Családi Angol programja Magyarországon [The Learning English Family Programme run by the British Council in Hungary]. In Márkus É., \& Trentinné Benkő É. (szerk.): A korai idegen nyelvi fejlesztés elmélete és gyakorlata. Konferenciaelöadásoke és báttértanulmányok. Budapest. ELTE Eötvös Kiadó. 107-115.

Fürész-Mayernik M.(2015): Angol kalauz a mondókák viláába [English Guide into the World of Nursery Rhymes], Katiötletek Nyomdai Ötletgyár, Mór.

http://ec.europa.eu/eurostat/web/productsstatistical-books/-/KS-HA-17-001. 2017.09.05.

http://eduline.hu/nyelvtanulas/2017/4/27/Nyelvt udas_nem_teszi_ki_Magyarorszag_az_abl_I08 H2S 2017.09.05.

Heller, C.y (2010): Non-Native Speakers Can Raise Multilingual Children! downloaded: 2014. 06. 25.

http://www.multilingualliving.com/2010/04/23/n on-native-speakers-can-raise-multilingualchildren.

King, K., \& Fegle, L.(2006): Raising bilingual Children: Common parental concerns and current research.

CalDigest. http://www.cal.org/resources/digest/digest_p dfs/RaiseBilingChildi.pdf downloaded: 2013. 04. 24.

Kósa, É. (2007): A média szerepe a gyerekeke fejlódésében [The Role of the Media in Children's Development]

www.mediatudor.hu/download/tudastar_szakir odalom_kosa.doc 2016.07.31.

Muszka, G. (2013): Az óvodás gyermek és az óvodai angoloktatás Debrecenben. [The kindergarden aged child and English teaching in kindergardens in Debrecen] Hajdúböszörmény. (thesis, manuscript)

Nemes, M. (2016): A nyelvhasználat lehetôségei a családban. [The possibilities of using languages in the family] In Vargáné dr. Nagy Anikó (szerk.) Családi nevelés. Didakt Kft. , Debrecen.

Nemes, M.(2018): A korai nyelvtanítás története Nyíregyházán a rendszerváltástól napjainkig. [History of early language teaching in Nyíregyháza since the change of the political regime to the present day] Különleges Bánásmód, 4.(1). 7-18. http://old.gyfk.unideb.hu/kulonlegesbanasmod /files/KB_2018_1_Nemes_Nagy.pdf

Nemes, M. (2017): A korai kezdés után - nyelvvizsgák gyerekeknek. [After an early start - language exams for children]. In Márkus É., M. Pintér T., \& Trentinné Benkő É. (szerk.): Jó gyakorlatok a korai idegennyelvi-fejlesatésben Oktatás, kutatás, fejlesztés. Budapest. ELTE TÓK. 7187.

Nemes M., \& Révészné Nagy O. (2017): A mesterséges kétnyelvűségrôl - angolul nevelő magyar családok [Raising bilingually - Hungarian families raising their child(ren) in English]. In Borsos É., Námesztovszki Zs., \& Németh F. (Szerk.). A Magyar Tannyelvü Tanitóképzó Kar 2017-es tudományos konferenciáinak tanulmánygyüjteménye. Szabadka. 997-1010. http://magister.uns.ac.rs/files/kiadvanyok/kon f2017/kotet/ConfSubotica2017.pdf

Nikolov M.a (2004): Az életkor szerepe a nyelvtanulásban. [The role of age in language learning] Modern Nyelvoktatás, 10. 1. 3-26.

Pearson, B. Z. (2008): Raising a Bilingual Child. Living Language.

Reilly, V. (2005, 2011): Cookie and friends. Oxford. Oxford University Press.

Saunders, G. (1988): Bilingual children: from birth to teens. Univerity of California. Multilingual Matters Ltd.

Selby, C., \& McKnight, L. (2006): Hippo and Friends. Cambridge. Cambridge University Press.

Tölgyessy, Zs. (2015): A médiapedagógia lehetséges elvei. [The possible principles of mediapedagogy] http://ovonok.hu/2015/01/amediapedagogia-lehetseges-elvei-az-ovodaban/ 2016.09.05.

Varga R. (2008): Hogyan tanítsd a gyerekedet angolul otthon, játék közben? [How to teach English to your child at home while playing] http://angolgyerekeknek.com/modszer/2016.08.15. 